\title{
COMPOSITION OF MICROBIAL PLFAs AND CORRELATIONS WITH TOPSOIL CHARACTERISTICS IN THE RARE ACTIVE TRAVERTINE SPRING-FED FEN
}

\author{
PETER HANAJÍK ${ }^{1}$, MILAN ZVARÍK ${ }^{2}$, HANNU FRITZE ${ }^{3}$, IVAN ŠIMKOVIC ${ }^{1}$, RÓBERT \\ KANKA $^{4}$ \\ ${ }^{1}$ Department of Soil Science, Faculty of Natural Sciences, Comenius University, Mlynská dolina, 84515 Bratislava, \\ Slovak Republic; e-mail: hanajik@gmail.com, simkovic@fns.uniba.sk \\ ${ }^{2}$ Department of Nuclear Physics and Biophysics, Faculty of Mathematics, Physics and Informatics, Comenius Uni- \\ versity, Mlynská dolina, 84248 Bratislava, Slovak Republic; e-mail: milan.zvarik@fmph.uniba.sk \\ ${ }^{3}$ Natural Resources Institute Finland (Luke), Jokiniemenkuja 1, BOX 18, FI-01301 Vantaa, Finland; e-mail: hannu. \\ fritze@luke.fi \\ ${ }^{4}$ Institute of Landscape Ecology SAS, Štefánikova 3, P.O.Box 254, 814 99, Bratislava, Slovak Republic; e-mail: robert. \\ kanka@savba.sk
}

\begin{abstract}
Hanajík P., Zvarík M., Fritze H., Šimkovic I., Kanka R.: Composition of microbial PLFAs and correlations with topsoil characteristics in the rare active travertine spring-fed fen. Ekológia (Bratislava), Vol. 35, No. 4, p. 295-308, 2016.

We studied soil PLFAs composition and specific soil properties among transect of small-scale fen in Stankovany, Slovakia. The aim of this study was to determine potential differences in the microbial community structure of the fen transect and reveal correlations among PLFAs and specific soil characteristics. PCA analyses of 43 PLFAs showed a separation of the samples along the axis largely influenced by i14:0, 16:1 $\omega 5$, br17:0, 10Me16:0, cy17:0, cy17:1, br18:0 and 10Me17:0. We measured a high correlation of sample scores and distance from fen edge (Kendall's test $\tau=0.857, P<0.01$ ). Kendall's test showed a negative correlation of PLFAs content ( $\mathrm{mol} \%$ ) and distance from the fen border for Gram $(+)$ bacteria, Actinomycetes, mid-chain branched saturated PLFAs and total PLFAs. The redundancy analysis of the PLFA data set for the eight samples using PLFAs as species and 21 environmental variables identified soil properties significantly associated with the PLFA variables, as tested by Monte Carlo permutation showing most significant environmental variables including dichlormethan extractables, water extractables, Klason lignin, acid-soluble lignin, holocellulose, total extractables, organic matter content, total PLFA amount, bacterial PLFA and total nitrogen negatively correlated to axis 1 and dry weight and carbonate carbon positively correlated to axis 1 . The amounts of Klason lignin, acid-soluble lignin, holocellulose total extractables, total PLFA, bacterial PLFA and total nitrogen were significantly correlated positively to the distance from fen border while moisture and total carbonate carbon were correlated negatively.
\end{abstract}

Key words: phospholipid fatty acids, organic $\mathrm{C}$ fractions, soil properties.

\section{Introduction}

As peat bogs and fens act as superior carbon stores, and because of their rare occurrence, they have a higher biodiversity value relative to other wetland types, they need to be pri- 
oritised for protection and restoration (van Roon, 2012). Peat bogs and fens in Slovakia represent endangered relict biotopes with unique flora and fauna communities, especially invertebrates. Formation of peatbogs and fens started here in the last ice age during Würm period, approximately 12,000-8,300 B.C. Climate conditions in Slovakia during this era were similar to the recent conditions in actual subarctic region and conditions in higher attitude were similar to conditions in actual arctic region (Jankovská, 1997). Peatland formation and development are mainly affected by climate, hydrological conditions and the topography of the subsoil (Shotyk et al., 2003). Hydrological functioning controls the physical, chemical and biological processes (Weiss et al., 2006) and hence is one of the most important factors regulating carbon fluxes (Binet et al., 2013; Wilson et al., 2011). Despite peatlands covering only a small percentage area among other ecosystems, its biodiversity and ecological functioning is very often of very high significance. Most of the species and populations inhabiting peatbog areas are highly sensitive to the changes in ecological conditions. Changes in land use or water regime of river basins can lead to the loss of biodiversity or irreversible changes in ecological functioning (Stanová, 2000).

Soil microorganisms respond to changing environmental conditions more quickly than most other soil constituents, which can be used as indicators of the changes in soil characteristics (Frostegård et al., 2011). Different approaches addressing microbial structure, composition or amount of microbial biomass have been developed. Methods such as polymerase chain reaction (PCR), quantitative polymerase chain reaction (qPCR), fatty acid methyl esters (FAMEs) analyses, denaturing gradient gel electrophoresis (DGGE), terminal restriction fragment length polymorphism (TRFLP), length heterogeneity polymerase chain reaction (LH-PCR) or genome sequencing (GS) are recently being used for identifying links between soil microbial diversity and enzymatic activity or microbial diversity, enzymatic activity and plant diversity (Vallejo et al., 2012; Welc et al., 2014). According to new approaches, biodiversity structure and redundancy are considered to be more of significance compared to quantification of microbial biomass. Although the amount of microbial biomass can be in positive or negative correlation with some of the soil functions and processes, specific changes in microbial community structure can affect species redundancy and soil processes intensity more significantly despite the same biomass amount (Barrios, 2007; Hajjar et al., 2008; Maron et al., 2011). The determination of the phospholipid fatty acid (PLFA) pattern of soil organisms has become commonly used method to study microbial community structure. PLFA method is a rapid and sensitive method to detect changes in the living microbial community in soil (Frostegård et al., 2011; Rousk et al., 2010). The PLFA approach can be used to reveal the structure of the variation in microbial communities.

The aim of this study was to determine potential changes in the microbial community structure of Natural Reservation Rojkov fen and understand the correlations among specific soil characteristics and PLFAs. We performed experiments to assess soil properties addressing the following questions: (1) Are there any differences in PLFAs composition along the fen transect sampling plots? (2) Do the soil properties vary according to distance from fen border? (3) Can we identify any correlations among composition of PLFAs and soil properties along fen transect? 


\section{Site description}

A small-scale fen situated in the municipality of Stankovany, district of Ružomberok, county of Žilina in Slovakia (GPS: N49 $14^{\prime} 77.35^{\prime \prime}$, E19 ${ }^{\circ} 15^{\prime} 39.38^{\prime \prime}$ ) was chosen for the study. The site is a nature reserve included in the Natura 2000 (code of territory SKUEV0238, Vel'ká Fatra Mts). It is one of the last active Intra-Carpathian travertine spring-fed fens with high content of carbonates. The area is protected since 1950 as a rare instance of co-occurring fen, mire and bog biocoenoses within a small area of 2.88 ha. Most of the area is covered with small raised hummocks and lower-lying bog hollows filled with water. Several natural or anthropogenic small ponds that can be found here are characteristic by continual release of gases (Chilová, 2000; Galvánek, 2007; IMCG, 2015). In our study, we focused on bigger homogeneous hummock-hollow part of the fen with no pond occurrence.

\section{Material and methods}

We sampled topsoil of $4 \times 80 \mathrm{~m}$ strip perpendicular to the main road I/18 taking three individual core samples, each of $10 \mathrm{~m}$. These three individual core samples were taken within 4 meters line parallel to the road and were mixed in one composite sample. After the plant material was removed, the eight composite samples were stored in plastic bags at $-20^{\circ} \mathrm{C}$ until used. Moisture was measured in situ at each plot by portable $\mathrm{HH} 2$ datalogger with probe.

To determine dry weight (d.w.) of the soil, samples were dried at $105^{\circ} \mathrm{C}$ for 24 hours. Soil organic matter content was measured as a loss on ignition from the dried samples at $550^{\circ} \mathrm{C}$ for $4 \mathrm{hrs}$. Since some of applied methods require small amount of the sample (mg), soil samples were additionally homogenized in zircon oxide mill. The content of carbon $(\mathrm{C})$, hydrogen $(\mathrm{H})$, nitrogen $(\mathrm{N})$, sulphur $(\mathrm{S})$ and oxygen $(\mathrm{O})$ was measured by elemental analyser Flash 2000 (Thermo Scientific).

The content of carbonate carbon $\left(\mathrm{C}-\mathrm{CO}_{3}\right)$ was determined by Fourier transform infrared (FTIR) spectroscopy by use of standard addition method $\left(\mathrm{CaCO}_{3}\right)$. The average absorbance determined at 2506 and $875 \mathrm{~cm}^{-1}$, respectively, was used (similarly as Tatzber et al., 2007) as the basis for carbonate quantification. The obtained $\mathrm{C}-\mathrm{CO}_{3}$ values were subsequently subtracted from total carbon content (TC, determined by FLASH 2000) in order to obtain organic carbon portions (OC). Transmission FTIR spectroscopy was performed in mid-infrared region (4000-400 $\mathrm{cm}^{-1}$ ) by using Nicolet 6700 spectrophotometer and Omnic 8 software (Thermo Scientific). In case of each sample, homogenized material ( $2 \mathrm{mg}$ ) was mixed with $\mathrm{KBr}(200 \mathrm{mg})$ and subsequently pressed into small disc. Each spectrum was obtained by averaging 128 scans, with spectral resolution of $4 \mathrm{~cm}^{-1}$.

For PLFA analysis, lipids were extracted from $2.0 \mathrm{~g}$ fresh weight soil amounts according to Bligh and Dyer (1959) and White et al. (1979) using chloroform, methanol and aqueous buffer system (1:2:0.8). The lipid extract was then fractionated into neutral lipids, glycolipids and polar lipids using silicic acid (King et al., 1977, Kates, 1986). The phospholipids was isolated from the lipid fraction and transesterified into fatty acid methyl esters (FAMEs), which were detected by gas chromatography (flame ionization detector) using a $50 \mathrm{~m} \mathrm{HP}-5$ (phenylmethyl silicone) capillary column. Helium was used as a carrier gas. The temperature of the oven was $50^{\circ} \mathrm{C}$ and it was raised at the rate of $30^{\circ} \mathrm{C} \mathrm{min}^{-1}$ to $160^{\circ} \mathrm{C}$, then at rate of $2{ }^{\circ} \mathrm{C} \mathrm{min}-1$ to $270{ }^{\circ} \mathrm{C}$ and at the end, oven was kept for $5 \mathrm{~min}$ at the final temperature of $270{ }^{\circ} \mathrm{C}$. The content of phospholipid fatty acids (PLFA, in mol\% - area \% of summed peak area) was identified based on a retention time index calculated relative to the retention times of the internal standards 13:0 and 19:0 (Hanajík, Fritze, 2009).

Organic nonpolar and polar fractions were analysed in the samples according to the method developed for peat samples (Karsisto et al., 2002, 2003) The total amount of nonpolar extractives was determined by dichlormethane extraction, and the amount of polar extractives was determined by acetone, ethanol and water extractions. Klason lignin and holocellulose were determined from extractive free residues, and acid-soluble lignin was analysed from Klason-lignin filtrate using Shimadzu 2401PC spectrophotometer.

Data were compiled and transformed in Microsoft Excel. Statistics and graphs were generated using R software, ver. 3.1.3, except for the redundancy analysis (RDA) and principal component analysis (PCA), which were calculated and graphed using CANOCO for Windows, version 4.5. For the PCA and RDA in this study, PLFAs were used 
as 'species'. The focus of the ordination was on the inter-species correlations, species scores were post-transformed (divided by the standard deviation) to reduce the effects of extreme values and the ordination was centred by species and samples. Qualitative assessment of each environmental factor in constrained ordination model was determined by Monte Carlo permutation method. Correlations between variables were made using a Kendall rank correlation coefficient. If the test statistic probability was less than the significance level $(\alpha=0.05)$, the null hypothesis for all tests was rejected.

\section{Results}

We analysed amounts of 43 PLFAs (Table 1) at studied area situated in Rojkov fen. Contents of lipids (mol\%) extracted from the soil samples were interpreted using principal component analysis (PCA) followed by Kendall's test of the PCA scores. Separation of the samples along axis 1 was largely influenced by i14:0, 16:1 $\omega 5$, br17:0, 10Me16:0, cy17:0, cy17:1, br18:0 and 10Me17:0 (Fig. 1). Principal component 1 (Axis 1) related to $49.51 \%$ of the variation in PLFA composition corresponds to a high correlation of sample scores and distance from fen border showed by Kendall's test $(\tau=0.857, P<0.01)$. Kendall's test showed a microbial community (MC) division at the studied site according to the distance of individual sampling plots from the fen border (Fig. 2).

$\mathrm{T}$ a b l e 1. Contents of 43 analyzed PLFA markers (in mol\%).

\begin{tabular}{|c|c|c|c|c|c|c|c|c|c|}
\hline PLFA & ROJ1 & ROJ2 & ROJ3 & ROJ4 & ROJ5 & ROJ6 & ROJ7 & ROJ8 & Marker \\
\hline \multicolumn{10}{|c|}{ Normal saturated } \\
\hline \multicolumn{10}{|c|}{ Mid-chain branched saturated } \\
\hline 10Me16:0 & 8.87 & 8.87 & 8.46 & 7.10 & 6.45 & 4.72 & 5.00 & 4.82 & Gram $(+)^{b c} ;$ Actinomycetes ${ }^{a, y}$ \\
\hline 10Me17:0 & 0.45 & 0.36 & 0.47 & 0.30 & 0.39 & 0.26 & 0.28 & 0.29 & Gram $(+)^{\mathrm{v}} ;$ Actinomycetes $^{\circ}$ \\
\hline 10Me18:0 & 0.75 & 0.58 & 1.02 & 0.50 & 0.93 & 1.00 & 0.68 & 0.62 & Gram $(+)^{\mathrm{v}}$; Actinomycetes ${ }^{\mathrm{a}, \mathrm{d}, \mathrm{y}}$ \\
\hline \multicolumn{10}{|l|}{ Saturated } \\
\hline \multicolumn{10}{|c|}{ Terminaly branched saturated } \\
\hline i14:0 & 2.07 & 1.72 & 1.51 & 1.29 & 1.57 & 1.08 & 1.00 & 1.49 & $\operatorname{Gram}(+)^{\mathrm{e}, \mathrm{y}}$ \\
\hline i15:0 & 6.33 & 6.20 & 6.38 & 5.61 & 6.37 & 5.34 & 5.92 & 6.81 & Gram $(+)^{\text {bcdfgy }}$ \\
\hline a15:0 & 6.33 & 6.45 & 6.29 & 6.09 & 6.64 & 5.18 & 5.28 & 6.88 & Gram $(+)^{\text {bdfgy }}$ \\
\hline i16:0 & 2.95 & 2.66 & 3.01 & 2.42 & 2.99 & 2.52 & 2.27 & 2.54 & $\operatorname{Gram}(+)^{\text {bcfgy }}$ \\
\hline i17:0 & 1.71 & 1.66 & 1.88 & 1.50 & 1.62 & 1.51 & 1.65 & 1.55 & $\operatorname{Gram}(+)^{\text {bdfgy }}$ \\
\hline a17:0 & 1.67 & 1.63 & 1.80 & 1.55 & 1.64 & 1.62 & 1.74 & 1.50 & $\operatorname{Gram}(+)^{\text {bdgy }}$ \\
\hline br18:0 & 0.95 & 0.83 & 0.83 & 0.58 & 0.56 & 0.39 & 0.49 & 0.56 & Gram $(+)^{\mathrm{v}}$; Methanothrops ${ }^{\mathrm{p}}$ \\
\hline br17:0 & 0.71 & 0.59 & 0.56 & 0.42 & 0.51 & 0.33 & 0.32 & 0.41 & Methanothrops $^{\mathrm{p}}$ \\
\hline br19:0 & 0.11 & 0.15 & 0.16 & 0.09 & 0.12 & 0.12 & 0.10 & 0.11 & General bacteria $^{z}$ \\
\hline delta18:0 & 0.23 & 0.17 & 0.18 & 0.12 & 0.24 & 0.16 & 0.13 & 0.13 & General biomarker $^{\mathrm{x}}$ \\
\hline \multicolumn{10}{|c|}{ Straight chain saturated } \\
\hline $14: 0$ & 1.23 & 1.20 & 1.29 & 1.41 & 1.65 & 1.42 & 1.31 & 1.50 & General bacteriag $^{\mathrm{g}}$ all organisms ${ }^{\mathrm{y}}$ \\
\hline $16: 0$ & 12.54 & 12.14 & 13.27 & 14.68 & 13.66 & 14.99 & 12.83 & 14.37 & $\begin{array}{l}\text { General bacteria }{ }^{\mathrm{m}}, \text { Eukaryotes }^{\mathrm{m}} \text { all } \\
\text { organisms }^{\mathrm{y}}\end{array}$ \\
\hline
\end{tabular}


$\mathrm{T}$ a b l e 1. Contents of 43 analyzed PLFA markers (in mol\%) - continued.

\begin{tabular}{|c|c|c|c|c|c|c|c|c|c|}
\hline PLFA & ROJ1 & ROJ2 & ROJ3 & ROJ4 & ROJ5 & ROJ6 & ROJ7 & ROJ8 & Marker \\
\hline $15: 0$ & 0.83 & 0.79 & 0.91 & 1.00 & 0.97 & 0.84 & 1.07 & 0.89 & General baceria $^{g}$ all organisms ${ }^{y}$ \\
\hline C17:0 & 0.75 & 1.61 & 1.18 & 0.79 & 1.07 & 0.88 & 5.60 & 1.20 & Methanothrophs ${ }^{t}$ \\
\hline C16:0 & 0.26 & 0.21 & 0.26 & 0.20 & 0.29 & 0.15 & 0.22 & 0.12 & Zoo- and phytoplankton $^{\mathrm{n}}$ \\
\hline $17: 0$ & 0.68 & 0.67 & 0.74 & 0.72 & 0.66 & 0.58 & 0.60 & 0.55 & General baceria $^{g}$ all organisms ${ }^{y}$ \\
\hline $18: 0$ & 2.00 & 1.77 & 2.39 & 2.13 & 2.21 & 2.49 & 1.96 & 1.81 & $\operatorname{Gram}(+)^{\mathrm{v}}$ all organisms ${ }^{\mathrm{y}}$ \\
\hline 20:0 & 0.33 & 0.33 & 0.40 & 0.38 & 0.38 & 0.76 & 0.38 & 0.34 & General bacteria $^{z}$ \\
\hline \multicolumn{10}{|c|}{ Monounsaturated } \\
\hline i16:1 & 0.64 & 0.57 & 0.48 & 0.35 & 0.55 & 0.56 & 0.47 & 0.45 & $\begin{array}{l}\text { Gram }(+)^{v} \text {; Actinobacteria, myxo- } \\
\text { bacteria, Flavobacterium-cytoph- } \\
\text { aga complexes and spore-forming } \\
\text { bacillir }\end{array}$ \\
\hline $16: 1 w 7 c$ & 10.00 & 11.10 & 9.91 & 12.05 & 11.09 & 11.63 & 10.68 & 13.85 & $\operatorname{Gram}(-)^{b, d}$ \\
\hline $16: 1 w 7 t$ & 0.87 & 0.84 & 0.82 & 1.00 & 1.16 & 1.02 & 0.79 & 0.97 & Gram (-) $)^{\mathrm{b}, \mathrm{g}}$ proteobacteria $^{y}$ \\
\hline 16:1w5 & 4.55 & 4.47 & 4.94 & 5.06 & 4.88 & 5.56 & 6.32 & 6.44 & Gram $(-)^{\mathrm{v}} ;$ AM fungi ${ }^{\mathrm{k}}$ bacteria $^{\mathrm{e}}$ \\
\hline 16:1w9 & 0.82 & 1.24 & 0.74 & 1.23 & 0.90 & 0.98 & 0.78 & 0.89 & General baceria $^{\mathrm{g}}$ \\
\hline $17: 1$ & 0.51 & 0.51 & 0.55 & 0.37 & 0.38 & 0.35 & 0.39 & 0.47 & Gram $(-)^{s}$ \\
\hline C15:1 & 0.07 & 0.06 & 0.05 & 0.07 & 0.07 & 0.05 & 0.07 & 0.05 & General biomarker $^{\mathrm{x}}$ \\
\hline 17:1w8 & 0.77 & 0.95 & 0.75 & 0.82 & 0.86 & 0.61 & 0.87 & 0.82 & Methanothrops ${ }^{\mathrm{u}}$ \\
\hline cy17:0 & 2.87 & 3.17 & 2.52 & 2.20 & 2.34 & 1.95 & 1.78 & 2.24 & $\operatorname{Gram}(-)^{b, c, d, f, g, j}$ \\
\hline $\mathrm{C} 17: 1$ & 0.16 & 0.12 & 0.13 & 0.11 & 0.11 & 0.04 & 0.04 & 0.04 & $\operatorname{Gram}(-)^{\mathrm{v}}$ \\
\hline cy19:0 & 3.47 & 2.80 & 3.00 & 2.30 & 3.06 & 2.57 & 1.94 & 1.54 & $\operatorname{Gram}(-)^{b, c, d, f, g, j}$ \\
\hline 18:1w9 & 5.77 & 5.46 & 5.84 & 5.27 & 5.77 & 6.56 & 5.68 & 5.59 & Fungi $^{1}$ Gram $(+)^{j}$ \\
\hline 18:1w7 & 13.98 & 14.46 & 12.75 & 13.14 & 13.84 & 15.17 & 12.79 & 12.55 & Gram $(-)^{v}$; General baceriag ${ }^{g, j}$ \\
\hline $18: 1$ & 1.03 & 1.12 & 1.25 & 0.98 & 0.95 & 1.42 & 1.48 & 1.78 & Methanothrops ${ }^{\mathrm{p}}$ \\
\hline $19: 1 a$ & 0.42 & 0.45 & 0.51 & 0.47 & 0.52 & 0.68 & 0.69 & 0.62 & $\operatorname{Gram}(-)^{\mathrm{v}}$ \\
\hline $18-\mathrm{OH}$ & 0.06 & 0.06 & 0.12 & 0.30 & 0.15 & 0.07 & 0.22 & 0.08 & General biomarker $^{\mathrm{x}}$ \\
\hline \multicolumn{10}{|c|}{ Polyunsaturated } \\
\hline $18: 2 \mathrm{c}$ & 0.12 & 0.12 & 0.13 & 0.11 & 0.10 & 0.08 & 1.41 & 0.11 & General biomarker $^{x}$ \\
\hline $18: 2 \mathrm{a}$ & 0.12 & 0.10 & 0.17 & 0.10 & 0.12 & 0.08 & 0.14 & 0.09 & Methanothrops ${ }^{\mathrm{p}}$ \\
\hline $18: 2 w 6$ & 1.71 & 1.48 & 2.03 & 4.65 & 1.80 & 3.86 & 4.00 & 2.38 & Fungi $i^{\mathrm{b}, c, \mathrm{~d}, \mathrm{~h}, \mathrm{i}}$, plants ${ }^{\mathrm{b}, e}$ \\
\hline $20: 5$ & 0.03 & 0.02 & 0.04 & 0.11 & 0.08 & 0.04 & 0.03 & 0.06 & arbuscular mycorrhizal fungusw \\
\hline $20: 4$ & 0.22 & 0.18 & 0.22 & 0.25 & 0.22 & 0.21 & 0.35 & 0.33 & arbuscular mycorrhizal fungus $^{w}$ \\
\hline $20: 2$ & 0.08 & 0.12 & 0.09 & 0.16 & 0.11 & 0.16 & 0.25 & 0.16 & Eucaryotic organizms $^{q}$ \\
\hline
\end{tabular}

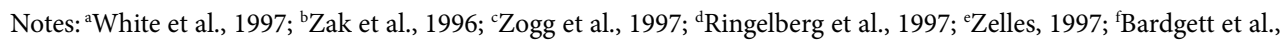
1996; ' Frostegård, Bååth, 1996; hinkart et al., 2002; 'Madan et al., 2002; 'Zelles, 1999; ' Sakamoto et al., 2004; ${ }^{1}$ Bååth, 2003; ${ }^{\mathrm{m} H e d r i c k}$ et al., 2007; ${ }^{\mathrm{n} C a n u e l}$ et al., 1995; ${ }^{\circ}$ Cooper et al., 2002; ${ }^{\mathrm{B} B u l l}$ et al., 2000; ${ }^{\mathrm{q}}$ Högberg et al., 2006; ${ }^{\mathrm{r} F r o u z}$ et al., 2013; 'Lost et al., 2008; 'Mohanty et al., 2006; "Holmes et al., 1999; 'Korkama et al., 2006; wAllison, Miller, 2004; ${ }^{\mathrm{x}}$ Hanajík, Fritze, 2009; ${ }^{\mathrm{y}} \mathrm{Palojärvi,} \mathrm{2006;}{ }^{\mathrm{z}} \mathrm{Hultman}$ et al., 2010. 


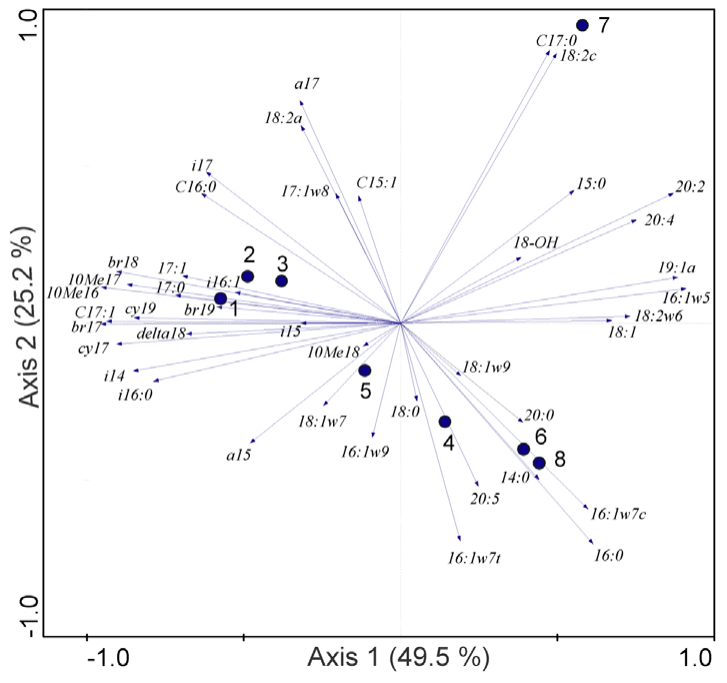

Fig. 1. Principal component analysis (PCA) of the PLFA data set for the 8 soil samples, using 43 PLFAs as species.

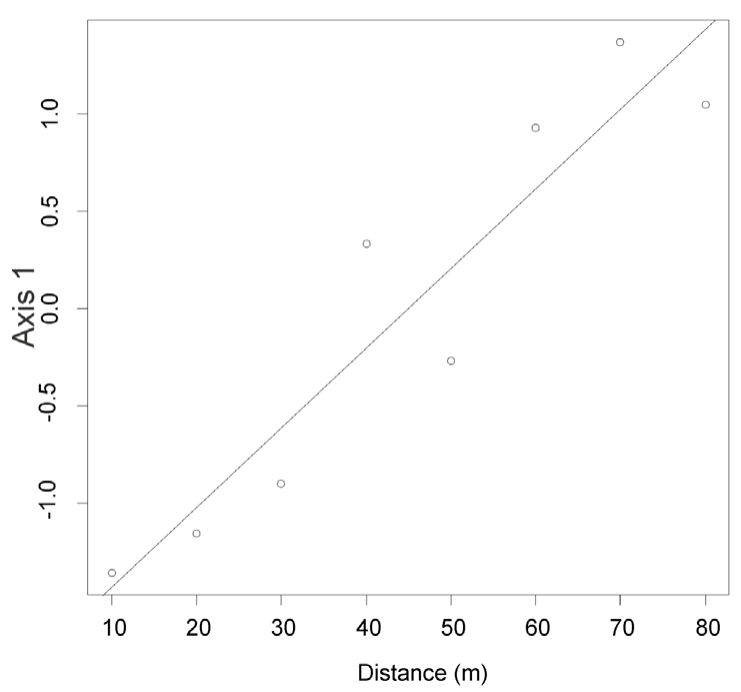

Fig. 2. Division of sampling plots from the fen border at studied site according to the distance, Kendall's test $(\tau=0.857, \mathrm{P}<0.01)$.
We divided PLFAs into several groups according to chemical structure or affiliation to specific group of microorganisms (Table 1). Kendall's test showed negative correlation of PLFA content (mol\%) and distance from the fen border for following groups of PLFA: Gram $(+)$ bacteria $(P<0.05, \tau=$ $-0,643)$, Actinomycetes $(P<0.01, \tau$ $=-0.857)$, mid-chain branched saturated PLFAs $(P<0.01, \tau=-0.929)$, total PLFAs $(P<0.05, \tau=-0.786)$ (Fig. 3). PCA of 21 environmental factors (Fig. 4) followed by Kendall's test revealed first principal component (axis 1) explaining $99.1 \%$ of the variation in environmental factors composition according to distance from the fen border ( $\tau=-0.786, P<0.01)$. Redundancy analysis (RDA), a linear canonical community ordination method, was used to visualise the relationships between the response variable values (PLFAs), the environmental variable gradients and the samples (Fig. 5). Environmental gradient arrows, which are longest, allow more confidence in the inferred correlations, which roughly indicates a larger effect of that variable on the total species (PLFA) variation (ter Braak, Smilauer, 2002), and point in the direction in which the site scores would move if the value of that environmental variable increased. RDA analysis identified those specific environmental variables significantly associated with the PLFA variables, as tested

by Monte Carlo permutation showing variables most significant for distribution including A $(P<0.05), \mathrm{D}(P<0.05), \mathrm{E}(P<0.01), \mathrm{F}(P<0.05), \mathrm{G}(P<0.01), \mathrm{H}(P<0,01), \mathrm{I}(P<0,05)$, 
$\mathrm{J}(P<0,05), \mathrm{L}(P<0,05), \mathrm{M}(P$ $<0,01), \mathrm{S}(P<0,05)$ and $\mathrm{V}(P<$ 0.01 ) (Fig. 5). Variables tested as significant (A, D, E, G, H, I, J, L, $\mathrm{M}$, and $\mathrm{S}$; see Fig. 5 text) were negatively correlated with Axis 1 and variables $\mathrm{F}$ and $\mathrm{V}$ were correlated positively to axis 1 .

\section{Discussion}

For analysing our data, we used a combination of statistical methods including principal component analysis (PCA), which is a technique aimed at emphasising variation and bringing out strong patterns in a data set and it is often used to make data easy to explore and visualise, Kendall rank correlation, which is a non-parametric test that measures the strength of dependence among variables and Monte Carlo permutation method used for the determination of qualitative measure of each factor in constrained ordination model.

Specific compounds were measured in soils of Rojkov peatland (Table 2) aiming to identify correlations with PLFAs distribution at the studied plots. We measured the amount of soluble compounds in dichlormethane, acetone, ethanol and water. Dichlormethane was used to remove non-polar extractives (e.g. fats, oils, resins, waxes, plant pigments, fatty alcohols and fatty acids) and acetone, ethanol and water to remove polar extractives (e.g. soluble carbohydrates, ketones, pectins and tannins) (Ryan et al., 1990; Wieder, Starr, 1998). Soluble components are generally considered to be the first attacked by decomposition of microorganisms and therefore also be the first to vanish, inflicting more
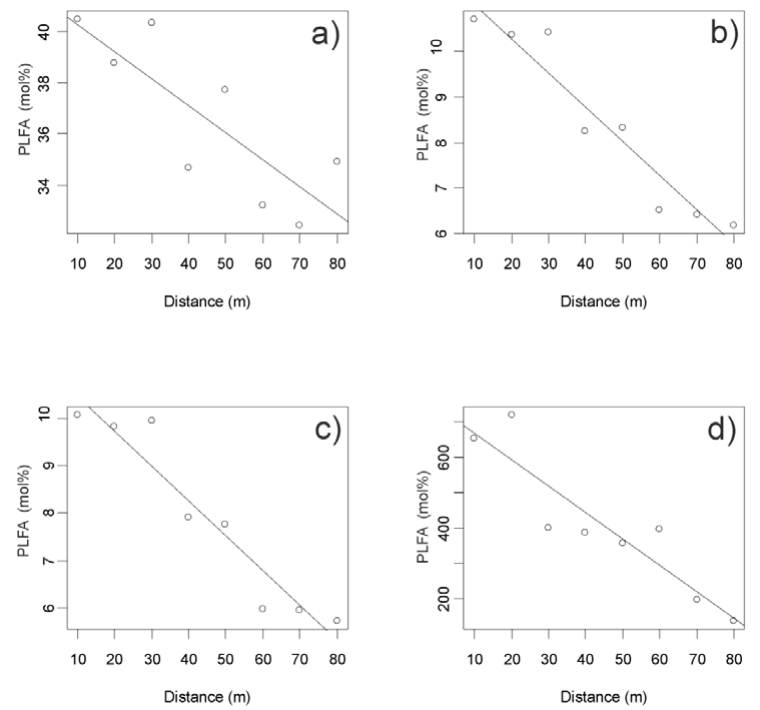

Fig. 3. Correlation among PLFAs groups (in mol\%) and distance from the fens border according to Kendall's test a) of Gram (+) bacteria, b) Actinomycetes, c) mid-chain branched saturated PLFAs and d) total amount of PLFA.

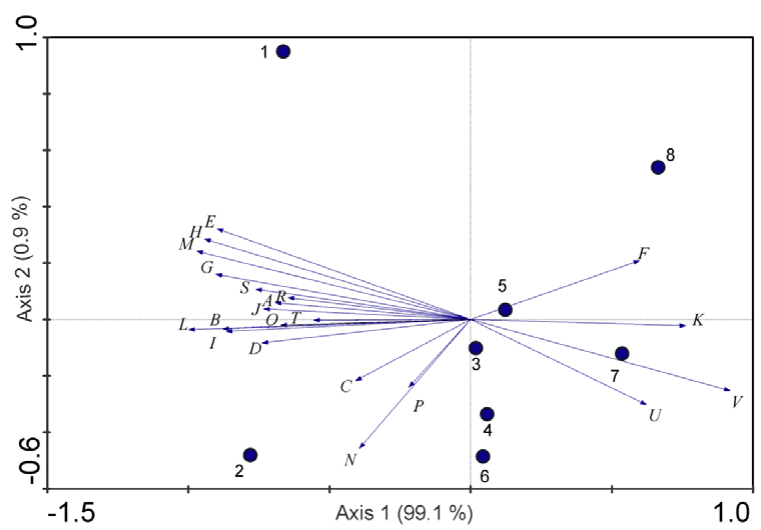

Fig. 4. PCA of 21 environmental factors. 


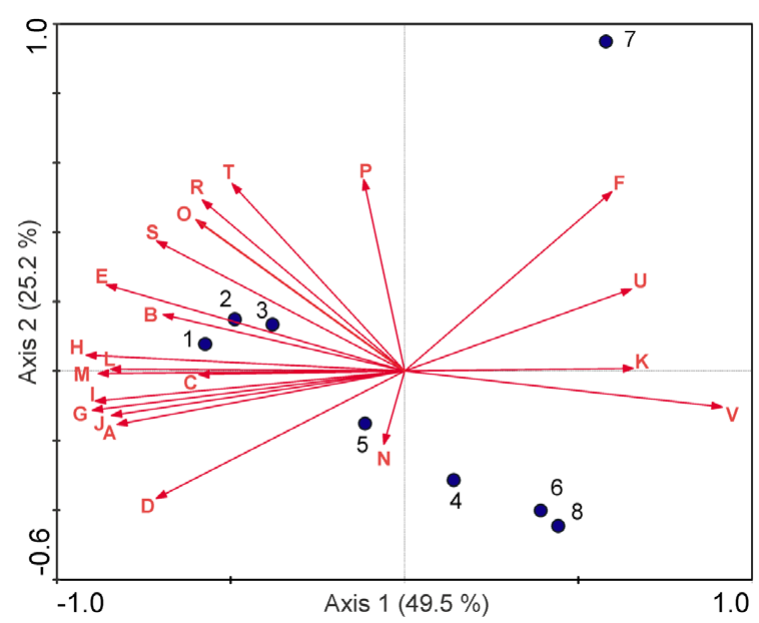

Fig. 5. The Redundancy analysis (RDA) of the PLFA data set for the 8 samples using 43 PLFA as species and 21 environmental variables. (A) weight loss \% of dichlormethan extractables, (B) weight loss \% of aceton extractables, (C) weight loss \% of ethanol extractables, (D) weight loss \% of water extractables, (E) \% of Klason lignin content, (F) dry weight \%, (G) acid soluble lignin content \%, (H) holocellulose content $\%$, (I) extractables total weight loss $\%$, (J) organic matter content $\mathrm{g} \mathrm{dw}^{-1}$, (K) moisture volume \%, (L) total PLFA amount in $\mathrm{nmol} \mathrm{gdw}^{-1}$, (M) bacterial of Klason lignin content in $\mathrm{nmol} \mathrm{gdw}^{-1}$, (N) fungal PLFA in $\mathrm{nmol} \mathrm{gdw}^{-1},(\mathrm{O})$ weight $\%$ of total organic carbon $(\mathrm{P})$ weight \% of total carbon, (R) weight \% of total hydrogen, (S) weight $\%$ of total nitrogen, (T) weight $\%$ of total sulfur, (U) weight $\%$ of total oxygen, (V) weight $\%$ of total carbonate carbon. rapid decomposition in substrates rich in easily soluble compounds. The amounts of water extractables were significantly associated with PLFAs composition at our plots (Table 3): extractable amounts of dichlormethane, acetone and ethanol were not tested significant. Plots with higher amounts of water-soluble components also contained higher amounts of organic matter and content of moisture was lower than 100 vol\% (Table 2) at these plots. Lower water content probably creates better conditions for plant growth and thus higher organic matter accumulation and increase in content of water-soluble components. The amount of water-soluble fraction is usually linked to early decomposition of various wood litter (Gholz et al., 2000; Trofymow et al., 2002; Vávřová et al., 2009) and can be suitable as a predicting variable for litter mass loss in decomposition modelling (Liski et al., 2005). Klason lignin, providing an approximate integration of the most insoluble lignin, cutin and tannin were not statistically significant for PLFA distribution. Holocellulose, representing sum of cellulose and hemicelluloses, was not significant for PLFAs distribution. We also analysed acid-soluble lignin (ASL), which is formed in Klason lignin determination and together with Klason lignin represents the relative total content of lignin. We measured amounts of total carbon (TC), hydrogen, nitrogen, sulphur, oxygen, $\mathrm{CO}_{3}$-carbon $\left(\mathrm{C}-\mathrm{CO}_{3}\right)$ and organic carbon $(\mathrm{OC})$ using elemental analyser. Only amounts of nitrogen and $\mathrm{C}-\mathrm{CO}_{3}$ showed statistical significance for PLFA distribution (Table 3). We also considered total amount of PLFA (mol\%), bacterial (nmol\%) and fungal (nmol\%) PLFA to be representative environmental factors. There are disadvantages of using PLFA for identifying specific groups of organisms, which is discussed in the article later. The total amount of PLFA (mol\%) and bacterial PLFA (nmol\%) were statistically significant for PLFA division (Table 3). Dry weight $\%$ of the samples, which represents the amount of soil (organic + inorganic constituents) with water excluded from the sample, loss of ignition giving picture about amount $\%$ of organic matter in the sample and moisture did not show statistical significance, although these characteristics can generally play a considerable role in shifting other soil properties. 


\begin{tabular}{|c|c|c|c|c|c|c|c|c|c|c|c|c|c|c|c|c|c|c|c|c|c|c|c|}
\hline$\frac{\hat{\beta}}{\hat{\delta}}$ & 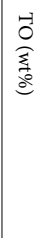 & 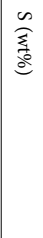 & $\begin{array}{l}z \\
z \\
\frac{z}{z} \\
\text { do }\end{array}$ & 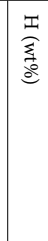 & 立。 & 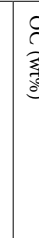 & 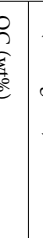 & 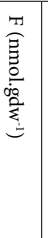 & 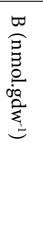 & 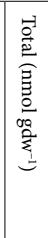 & 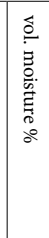 & 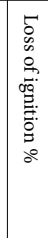 & 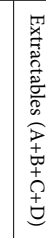 & & 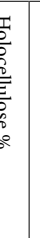 & 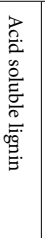 & 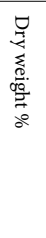 & 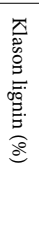 & 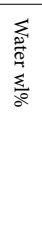 & 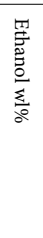 & 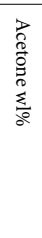 & & \\
\hline$<$ & a & $\rightarrow$ & is & $\nexists$ & סי & 0 & o & z & $z$ & $r$ & $\pi$ & - & - & & I & 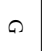 & TI & $\pi$ & $\theta$ & 0 & $\infty$ & $>$ & $\frac{8}{\circ}$ \\
\hline 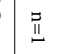 & II & II & II & II & iI & II & II & II & 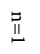 & 芩 & $\underset{\omega}{\tilde{u}}$ & $\underline{\underline{I}}$ & III & & i & $\underset{I}{\|}$ & 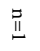 & $\underset{\sim}{n}$ & $\underset{\sim}{\mathbb{N}}$ & $\underset{\sim}{\pi}$ & $\underset{\sim}{\pi}$ & in & $=$ \\
\hline 远 & 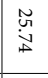 & $\underset{\infty}{\underset{\infty}{\tilde{N}}}$ & $\vec{i}$ & $\stackrel{\omega}{i}$ & 总 & : & & $\overrightarrow{\dot{\infty}}$ & 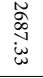 & $\begin{array}{l}\text { 彳े } \\
\text { 商 }\end{array}$ & 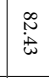 & $\dot{\circ}$ & స̃ & & G & $\vec{\sigma}$ & 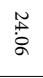 & 岕 & $\begin{array}{l}N \\
\infty \\
\infty \\
\infty\end{array}$ & $\overrightarrow{5}$ & 峁 & in & \\
\hline & & & & & & & & & & & It & & & & + & $1+$ & & $1+$ & $1+$ & $1+$ & $1+$ & $1+$ & , \\
\hline & & & & & & & & & & & 岕 & & & & ह & i & & 它 & i & $\stackrel{\circ}{\dot{v}}$ & $\stackrel{\dot{\infty}}{\infty}$ & 总 & \\
\hline i & $\stackrel{\tilde{H}}{\stackrel{\tilde{H}}{*}}$ & $\underset{\tilde{N}}{\stackrel{0}{n}}$ & $\overline{\tilde{N}}$ & 岕 & مِّف & 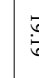 & t. & 蒿 & 总 & $\begin{array}{l}\mathcal{N} \\
\text { Oे } \\
\text { N }\end{array}$ & 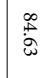 & $\stackrel{8}{:}$ & 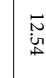 & & $\begin{array}{l}6 \\
\text { b }\end{array}$ & $\overrightarrow{+}$ & $\begin{array}{l}\tilde{\mathscr{O}} \\
\stackrel{\infty}{\infty}\end{array}$ & 点 & $\begin{array}{l}N \\
\infty \\
\infty \\
\infty\end{array}$ & 悹 & $\stackrel{w}{\dot{w}}$ & بू & \\
\hline & & & & & & & & & & & $1+$ & & & & + & $1+$ & & $1+$ & $1+$ & $1+$ & $1+$ & $1+$ & $\stackrel{N}{N}$ \\
\hline & & & & & & & & & & & $\underset{\stackrel{\infty}{\infty}}{\stackrel{\omega}{\infty}}$ & & & & 䛼 & $\underset{\text { i }}{\text { D }}$ & & $\dot{ن}$ & $\underset{\sim}{\stackrel{i}{u}}$ & $\dot{\tilde{O}}$ & $\overrightarrow{\dot{\infty}}$ & $\stackrel{\dot{0}}{\mathrm{v}}$ & \\
\hline$\ddot{g}$ & 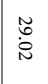 & i & ĩ & $\stackrel{n}{y}$ & 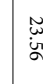 & 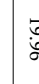 & : & $\stackrel{\infty}{\infty}$ & 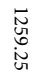 & 志 & $\begin{array}{l}\infty \\
\stackrel{\infty}{t} \\
\stackrel{v}{v}\end{array}$ & $\vec{\Sigma}$ & 5 & & سّ & $\underset{\sim}{\tilde{N}}$ & 莣 & $\begin{array}{l}\tilde{N} \\
\alpha \\
\alpha\end{array}$ & $\begin{array}{l}N \\
\infty \\
\infty \\
\infty\end{array}$ & i & : & $\dot{\hat{o}}$ & \\
\hline & & & & & & & & & & & ${ }_{1+}$ & & & & + & $1+$ & & $1+$ & $1+$ & $1+$ & $1+$ & $1+$ & \\
\hline & & & & & & & & & & & $\underset{\substack{n \\
\infty}}{\substack{\infty \\
\infty}}$ & & & & 8 & : & & $\stackrel{N}{\tilde{u}}$ & $\stackrel{\dot{\infty}}{\dot{\infty}}$ & 总 & $\stackrel{8}{\mathrm{~N}}$ & : & \\
\hline ळे & $\underset{\infty}{\stackrel{N}{\sim}}$ & $\dot{8}$ & 岕 & $\vec{v}$ & $\begin{array}{c}\mathbf{v} \\
\vdots \\
i\end{array}$ & 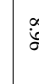 & & 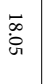 & $\underset{\omega}{\Xi}$ & $\begin{array}{l}\omega \\
\infty \\
\infty \\
\stackrel{\infty}{\infty}\end{array}$ & 형 & : & gे & & $\begin{array}{l}\dot{\infty} \\
\dot{0}\end{array}$ & $\begin{array}{l}0 \\
\dot{0}\end{array}$ & $\stackrel{\text { 莣 }}{\stackrel{n}{N}}$ & స్ & $\tilde{\ddot{\infty}}$ & $\vec{E}$ & i & $\begin{array}{l}w \\
\infty \\
\infty\end{array}$ & $\widetilde{\pi}$ \\
\hline & & & & & & & & & & & $1+$ & & & & $1+$ & $1+$ & & $1+$ & $1+$ & It & $1+$ & $1+$ & \\
\hline & & & & & & & & & & & $\ddot{8}$ & & & & i & $\dot{\omega}$ & & $\underset{\substack{\infty \\
\leftrightarrow}}{\vec{b}}$ & $\dot{0}$ & i & $\stackrel{\dot{\omega}}{\dot{\omega}}$ & $\dot{\dot{v}}$ & \\
\hline छे & 岕 & : & : & $\underset{\sim}{\infty}$ & i্ & 袋 & E & 岕 & 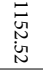 & $\begin{array}{l}\text { U. } \\
\text { ज़ }\end{array}$ & 。ั. & نे & i & & 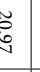 & $\overrightarrow{\vec{v}}$ & 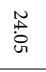 & 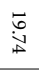 & 畓 & 管 & :ंنे & $\begin{array}{l}u \\
\tilde{\sigma}\end{array}$ & \\
\hline & & & & & & & & & & & $1+$ & & & & $1+$ & $1+$ & & $1+$ & $1+$ & It & $1+$ & $1+$ & $\widetilde{\widetilde{v}}$ \\
\hline & & & & & & & & & & & $\dot{8}$ & & & & i & $\stackrel{\leftrightarrow}{v}$ & & in & : & $\dot{\vec{\sigma}}$ & $\stackrel{i}{i}$ & $\stackrel{\circ}{\dot{v}}$ & \\
\hline தे & $\begin{array}{l}\underset{\sim}{\tilde{\Delta}} \\
\dot{\Delta}\end{array}$ & $\stackrel{i}{i}$ & : & 莣 & 惫 & 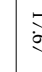 & كु & 苑 & $\begin{array}{l}\bar{ज} \\
\text { : } \\
\text { : }\end{array}$ & $\begin{array}{l}\text { w } \\
\text { ज़ } \\
\text { ज. }\end{array}$ & 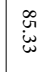 & 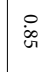 & 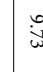 & & : & $\stackrel{\vec{\infty}}{\vec{\infty}}$ & 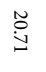 & $\begin{array}{l}\overline{\hat{\alpha}} \\
\dot{\infty}\end{array}$ & $\ddot{\ddot{8}}$ & $\tilde{\omega}$ & ì & 点 & \\
\hline & & & & & & & & & & & $1+$ & & & & $1+$ & $1+$ & & $1+$ & $1+$ & It & $1+$ & $1+$ & 의 \\
\hline & & & & & & & & & & & $\dot{\omega}$ & & & & 它 & i & & 宛 & $\dot{0}$ & 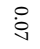 & 앵 & $\underset{\infty}{\stackrel{\circ}{\infty}}$ & \\
\hline : & \begin{tabular}{|c}
$\stackrel{\omega}{\sim}$ \\
d
\end{tabular} & i & $\stackrel{\circ}{\infty}$ & 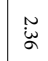 & 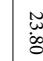 & 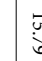 & जु & م) & 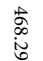 & $\begin{array}{l}\vec{\sigma} \\
\text { 心 } \\
\text { s }\end{array}$ & $\begin{array}{l}\overrightarrow{8} \\
\dot{8}\end{array}$ & iे & v & & it & i & 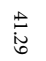 & $\begin{array}{l}\vec{i} \\
\dot{0}\end{array}$ & 点 & ì & in & $\begin{array}{c}N \\
\substack{\infty \\
\sim}\end{array}$ & \\
\hline & & & & & & & & & & & $1+$ & & & & $1+$ & $1+$ & & It & $1+$ & $1+$ & $1+$ & $1+$ & $\stackrel{\widetilde{g}}{\widetilde{g}}$ \\
\hline & & & & & & & & & & & $\dot{8}$ & & & & i & $\dot{\circ}$ & & $\underset{\sigma}{\omega}$ & $\stackrel{\circ}{\mathrm{N}}$ & $\stackrel{\circ}{\circ}$ & $\stackrel{\circ}{\dot{\omega}}$ & $\stackrel{\dot{\vartheta}}{\mathrm{v}}$ & \\
\hline $\begin{array}{l}\text { ¿े } \\
\infty\end{array}$ & $\begin{array}{l}\tilde{\sigma} \\
\dot{\tilde{b}} \\
\end{array}$ & 8े & $\underset{\infty}{\stackrel{\infty}{\infty}}$ & $\dot{\alpha}$ & $\begin{array}{l}\bar{v} \\
\text { t. }\end{array}$ & 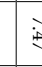 & t & 岕 & 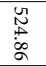 & 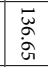 & $\begin{array}{l}\overrightarrow{0} \\
\dot{8}\end{array}$ & i & 品 & & $\begin{array}{l}\infty \\
8 \\
8\end{array}$ & $\stackrel{8}{8}$ & $\begin{array}{l}\omega \\
\text { w } \\
\text { s. }\end{array}$ & $\begin{array}{l}\vec{w} \\
\vec{\omega} \\
\dot{\omega}\end{array}$ & 宓 & iू & i্ & $\begin{array}{l}n \\
\infty \\
\infty \\
\infty\end{array}$ & \\
\hline & & & & & & & & & & & $1+$ & & & & $1+$ & $1+$ & & $1+$ & $1+$ & It & $1+$ & $1+$ & $\widetilde{\tilde{\sigma}}$ \\
\hline & & & & & & & & & & & $\dot{8}$ & & & & ن & ¿̊ & & ĩ & $\dot{0}$ & 总 & $\stackrel{8}{\mathrm{v}}$ & 总 & \\
\hline
\end{tabular}


T a b l e 3. Environmental characteristics statistically significant for PLFA spatial division using RDA and characteristics with significant correlation to spatial distribution according to distance from the fen border tested by Kendall's test (X stands for $\mathrm{P}<0.05$; + stands for positive correlation). See Figure 5 for explaining abbreviations of environmental characteristics.

\begin{tabular}{|l|c|c|c|c|c|c|c|c|c|c|c|c|c|c|c|c|c|c|c|c|c|}
\hline Environmental characteristics \\
\hline code & A & B & C & D & E & F & G & H & I & J & K & L & M & N & O & P & R & S & T & U & V \\
\hline RDA & - & - & - & X & - & - & - & - & - & - & - & X & X & - & - & - & - & X & - & - & X \\
\hline Kendall & - & - & - & - & X & - & X & X & X & - & $+\mathrm{X}$ & X & X & - & - & - & - & X & - & - & + X \\
\hline
\end{tabular}

Kendall's test showed (E) Klason lignin content (\%), (G) acid-soluble lignin content (\%), $(\mathrm{H})$ holocellulose content (\%), (I) total weight loss (\%) of extractables, (K) moisture volume (\%), (L) total PLFA amount (in nmol $\mathrm{gdw}^{-1}$ ), (M) bacterial PLFA amount (in $\mathrm{nmol} \mathrm{gdw}^{-1}$ ), (S) total nitrogen $(\% \mathrm{DW})$ and $(\mathrm{V})$ total carbonate carbon $(\% \mathrm{DW})$ significantly correlated to the distance from the fen border. E, G, H, I, L, M and S were correlated negatively (amounts were decreasing from plot 1 to plot 8 ) and $\mathrm{K}$ and $\mathrm{V}$ were correlated positively (amounts were increasing from plot 1 to plot 8). Environmental factors identified by RDA (D, L, M, S and $\mathrm{V}$ ), which significantly influenced the PLFA division, were also significantly correlated to the distance from the border except characteristic (D) weight loss (\%) of water extractables, which were significant for PLFA division but Kendall's test didn't show significant correlation to distance from fen border. E, G, H, I and K showed significant correlation to distance but were not identified by RDA as significant for PLFA division.

There are two main approaches that can be used to analyse PLFA data. Analysing the whole PLFA pattern by processing through the multivariate statistical technique, which can be followed by comparison of individual PLFAs, which answers the question if there are any changes in microbial community structure, or second approach focusing on revealing effects on specific groups of microorganisms assuming that certain PLFAs can serve as unique signatures for specific functional groups of microorganisms. Good marker PLFAs exist in very specific cases, thus caution must be taken in interpreting PLFAs (Frostegård et al., 2011). Most of PLFAs cannot be used as biomarkers for the detection of individual species due to overlapping PLFA patterns; however, comparison of total community PLFA profiles accurately mirrors shifts in community composition and provides a way to link community composition to specific metabolic and environmental conditions (Palojärvi, 2006). We focused mainly on the whole picture of PLFA composition at studied plots and effect of chemical characteristics on this composition. Analysing relationships among chemical characteristics and specific groups of microorganisms identified according to PLFAs biomarkers was not main purpose of this paper. For analysing PLFAs, we used principal component analysis (PCA), which is a technique used to emphasise variation and bring out strong patterns in a data set. It is often used to make data easy to explore and visualise.

The arrows in the resulting ordination diagrams point in the direction of maximum variation in the PLFAs, and the arrow length is proportional to the rate of change. PLFAs near the edge of the plot are most important in explaining plot differences, while PLFAs near the centre are of lesser importance. PLFA arrows pointing in the same general direction as environmental arrows can be interpreted as correlating well with that variable, and the longer the arrows is, the more confidence can be assumed in that correlation (ter Braak, 1994). 
PCA revealed subset of PLFAs important in explaining the variation in the data. Separation of the samples along axis 1 was largely influenced by i14:0, 16:1 $\omega 5$, br17:0, 10Me16:0, cy17:0, cy17:1, br18:0 and 10Me17:0. PLFA 10Me16:0 and 10Me17:0 are considered to be markers for $\mathrm{G}(+)$ bacteria and actinomycetes, i14:0 is marker for $\mathrm{G}(+)$ bacteria, br17:0 and br18:0 are markers for methanotrophs, 16:1 15 is a marker for $\mathrm{G}(-)$ bacteria and AM fungi, cy17:0 and C17:1 are markers for $\mathrm{G}(-)$ bacteria (Table 1).

Kendall's test of PLFAs revealed specific pattern of PLFAs spatial distribution depending on the distance of sampling plots from the fen border. These shifts in composition of microbial community suggest differences in environmental conditions at individual plots affecting microbial populations, which was proved by testing individual factors using Kendall's test revealing specific characteristics with high positive or negative correlation to distance from the fen border (Table 3).

\section{Conclusion}

PCA of 43 PLFAs analysed in Rojkov fen samples revealed a subset of PLFAs important in explaining the variation in the data. Separation of the samples along the axis are largely influenced by i14:0, 16:1 $\omega 5$, br17:0, 10Me16:0, cy17:0, cy17:1, br18:0 and 10Me17:0. Principal component 1 (axis 1) explaining $49.5 \%$ of the variation in PLFA composition corresponded to a high correlation of sample scores and distance from fen edge (Kendall's test $\tau=0.857, P<0.01)$. Kendall's test showed a negative correlation of content of PLFAs $(\mathrm{mol} \%)$ and distance from the fen border for following groups of PLFA: Gram $(+)$ bacteria $(P<0.05, \tau=-0.643)$, Actinomycetes $(P<0.01, \tau=-0.857)$, mid-chain branched saturated PLFAs $(P<0.01, \tau=-0.929)$ and total PLFAs $(P<0.01, \tau=-0.786)$. The redundancy analysis of the PLFA data set for the eight samples using PLFA as species and 21 environmental variables identified those specific soil properties significantly associated with the PLFA variables, as tested by Monte Carlo permutation showing the most significant environmental variables including dichlormethan extractables $(P<0.01)$, e.g. fats, oils, resins, waxes, plant pigments, fatty alcohols, fatty acids; water extractables $(P<0.05)$ e.g. soluble carbohydrates, ketones, pectins, tannins; Klason lignin $(P<0.01)$, acid soluble lignin $(P<0.01)$, holocellulose $(P<0,01)$, total extractables $(P<0,01)$, organic matter content $(P<0,05)$, total PLFA amount $(P<0,01)$, bacterial PLFA $(P<0,01)$, total nitrogen $(P<0,05)$ negatively correlated to axis 1 and dry weight $(P<0.05)$ and carbonate carbon $(P<0.01)$ positively correlated to axis 1 . Kendall's test of individual soil properties showed amounts of Klason lignin, acid-soluble lignin, holocellulose total extractables, total PLFA, bacterial PLFA and total nitrogen significantly correlated to the distance from fen border while moisture and total carbonate carbon were correlated negatively. PCA of 21 environmental factors (Figure 4), followed by Kendall's test, revealed principal component (Axis 1) explaining 99.1\% of the variation in environmental factors composition according to distance from the fen border $(\tau=-0.786, P<0.01)$.

\section{Acknowledgements}

This work is part of VEGA 1/0365/14 and APVV-0866-12 projects. 


\section{References}

Allison, V.J. \& Miller R.M. (2004). Using fatty acids to quantify arbuscular mycorrhizal fungi. In G. Podila \& A. Varma (Eds.), Mycorrhizae: basic research and applications (pp. 141-161). New Delhi: I.K. International Pvt. Ltd.

Bååth, E. (2003). The use of neutral lipid fatty acids to indicate the physiological conditions of soil fungi. Microb. Ecol., 45, 373-383. DOI: 10.1007/s00248-003-2002-y.

Bardgett, R.D., Hobbs, P.J. \& Frostegård A. (1996). Changes in soil fungal: bacterial biomass ratios following reductions in the intensity of management of an upland grassland. Biol. Fertil. Soils, 22, 261-264. DOI: 10.1007/ bf00382522.

Barrios, E. (2007). Soil biota, ecosystem services and land productivity. Ecological Economics, 64, 269-285. DOI: 10.1016/j.ecolecon.2007.03.004.

Binet, S., Gogo, S. \& Laggoun-Défarge F. (2013). A water-table dependent reservoir model to investigate the effect of drought and vascular plant invasion on peatland hydrology. J. Hydrol., 499, 132-139. DOI: 10.1016/j. jhydrol.2013.06.035.

Bligh, E.G. \& Dyer W.J. (1959). A rapid method of total lipide extraction and purification. Can. J. Biochem. Physiol., 37, 911-917. DOI: 10.1139/o59-099.

Bull, I.D., Nisha, R.P., Grahame, H.H., Ineson, P. \& Evershed R.P. (2000). Detection and classification of atmospheric methane oxidizing bacteria in soil. Nature, 405, 175-178. DOI: 10.1038/35012061.

Canuel, E.A., Cloern, J.E., Ringelberg, D.B., Guckert, J.B. \& Rau G.H. (1995). Molecular and isotopic tracers used to examine sources of organic matter and its incorporation into the food webs of San Francisco Bay. Limnol. Oceanogr., 40(1), 67-81. DOI: 10.4319/lo.1995.40.1.0067.

Chilová, V. (2000). Selected peatland ecosystems of the Protected Landscape Area Velká Fatra and the contiguous territory of Turiec basin (in Slovak). In V. Stanová (Ed.), Rašeliniská Slovenska (pp. 63-68). Bratislava: Daphne - Inštitút aplikovanej ekológie.

Cooper, J.N., Anderson, J.G. \& Campbell C.D. (2002). How resilient are microbial communities to temperature changes during composting? In H. Insam, N. Riddech \& S. Klammer (Eds.), Microbiology of Composting (pp. 3-16). Berlin: Springer. DOI: 10.1007/978-3-662-08724-4_1.

Frostegård, Å. \& Bååth E. (1996). The use of phospholipid fatty acid analysis to estimate bacterial and fungal biomass in soil. Biol. Fertil. Soils, 22, 59-65. DOI: 10.1007/BF00384433.

Frostegård, Å., Tunlid, A. \& Bååth E. (2011). Use and misuse of PLFA measurements in soils. Soil Biol. Biochem., 43, 1621-1625. DOI: 10.1016/j.soilbio.2010.11.021.

Frouz, J., Elhottová, D., Baldrián, P., Chroňáková, A., Lukešová, A., Nováková, A. \& Krištůfek V. (2013). Soil microflora development in post-mining sites. In J. Frouz (Ed.), Soil biota and ecosystem development in post mining sites (pp. 105-131). CRC Press. DOI: 10.1201/b15502-8.

Galvánek, D. (Ed.) (2007). Unique botanical areas in Slovakia (in Slovak). Bratislava: Daphne - Inštitút aplikovanej ekológie.

Gholz, H.L., Wedin, D.A., Smitherman, S.M., Harmon, M.E. \& Parton W.J. (2000). Long-term dynamics of pine and hardwood litter in contrasting environments: toward a global model of decomposition. Global Change Biology, 6, 751-765. DOI: 10.1046/j.1365-2486.2000.00349.x.

Hajjar, R., Jarvis, D.I. \& Gemmill-Herren B. (2008). The utility of crop genetic diversity in maintaining ecosystem services. Agric. Ecosyst. Environ., 123, 261-270. DOI: 10.1016/j.agee.2007.08.003.

Hanajík, P. \& Fritze H. (2009). Effects of forest management on soil properties at windthrow area in Tatra National Park (TANAP). Acta Environmentalica Universitatis Comenianae, 17(2), 36-46.

Hedrick, D.B., Peacock, A.D. \& White D.C. (2007). Lipid analyses for viable microbial biomass, community composition, metabolic status, and in situ metabolism. In C.J. Hurst, R.L. Crawford, J.L. Garland, D.A. Lipson, A.L. Mills \& L.D. Stetzenbach (Eds.), Manual of environmental microbiology (pp. 112-125). Washington: ASM Press.

Högberg, M.N., Högberg, P. \& Myrold D.D. (2006). Is microbial community composition in boreal forest soils determined by pH, C-to-N ratio, the trees, or all three? Oecologia, 150, 590-601. DOI: 10.1007/s00442-006-0562-5.

Holmes, A.J., Roslev, P., McDonald, I.R., Iversen, N., Henriksen, K. \& Murrell J.C. (1999). Characterization of methanotrophic bacterial populations in soils showing atmospheric methane uptake. Appl. Environ. Microbiol., 65, 3312-3318.

Hultman, J., Vasara, T., Partanen, P., Kurola, J., Kontro, M.H., Paulin, L., Auvinenm, P. \& Romantschuk M. (2010). Determination of fungal succession during municipal solid waste composting using a cloning-based analysis. J. Appl. Microbiol., 108, 472-487. DOI: 10.1111/j.1365-2672.2009.04439.x. 
IMCG-International Mire Conservation Group (2015). Threatened Peatlands of the World, Natural reserve Rojkovské rašelinisko, Rojkov Fen Nature Reserve, SR. http://www.imcg.net/pages/topics/threat/rojkov-fen.php [3.02.2015].

Jankovská, V. (1997). Evolution of peatbogs in Czech and Slovak Republic and cryogenic aspects - facts and hypothesis (in Slovak). In T. Baranec (Ed.), Flóra a vegetácia rašelinísk (pp. 51-54). Nitra: SPU.

Karsisto, M., Kitunen, V., Laiho, R., Laine, J., Tiainen, U., Savitski, M. \& Penttilä T. (2002). Identification and quantification of organic fractions in litter and peat organic matter during decomposing processes. In L. Pietola \& M. Esala (Eds.), Maa, josta elämme. II. Maaperätieteiden päivät, Helsinki 19.-20.11.2002. Laajennetut abstraktit. Pro Terra, 15, 36-38.

Karsisto, M., Savitski, M., Kitunen, V., Penttilä, T., Laine, J. \& Laiho R. (2003). Quantification of organic fractions in litter and peat organic matter. In J.O. Honkanen \& P.S. Koponen (Eds.), Proceedings of Sixth Finnish Conference of Environmental Sciences (pp. 135-137). Joensuu, May 8-9, 2003. Current Perspectives in Environmental Science and Technology. Finnish Society for Environmental Sciences, University of Joensuu.

Kates, M. (1986). Techniques in lipidology: isolation, analysis, and identification of lipids. Amsterdam: Elsevier.

King, J.D., White, D.C. \& Taylor C.W. (1977). Use of lipid composition and metabolism to examine structure and activity of estuarine detrial microflora. Appl. Environ. Microbiol., 33, 1177-1183.

Korkama, T., Fritze, H., Pakkanen, A. \& Pennanen T. (2006). Interactions between extraradical ectomycorrhizal mycelia, microbes associated with the mycelia and growth rate of Norway spruce (Picea abies) clones. New Phytol., 173, 798-807. DOI: 10. 1111/j.1469-8137.2006.01957.x.

Liski, J., Palosuo, T., Peltoniemi, M. \& Sievänen R. (2005). Carbon and decomposition model Yasso for forest soils. Ecol. Model., 189, 168-182. DOI: 10.1016/j.ecolmodel.2005.03.005.

Lost, S., Makeschin, F., Abiy, M. \& Haubrich F. (2008). Biotic soil activities. In E. Beck, J. Bendix, I. Kottke, F. Makeschin \& R. Mosandl (Eds.), Gradients in a tropical mountain ecosystem of Ecuador. Ecological Studies, 198, 217-227. DOI: 10.1007/978-3-540-73526-7.

Madan, R., Pankhurst, C., Hawke, B. \& Smith S. (2002). Use of fatty acids for identification of AM fungi and estimation of the biomass of AM spores in soil. Soil Biol. Biochem., 34, 125-128. DOI: 10.1016/S0038-0717(01)00151-1.

Maron, P. A., Mougel, C. \& Ranjard L. (2011). Soil microbial diversity: Methodological strategy, spatial overview and functional interest. C. R. Biol., 334, 403-411. DOI: 10.1016/j.crvi.2010.12.003.

Mohanty, S.R., Bodelier, P.L.E. \& Corad V.F.R. (2006). Differential effects of nitrogenous fertilizers on methaneconsuming microbes in rice field and forest soils. Appl. Environ. Microbiol., 72, 1346-1354. DOI: 10.1128/ AEM.72.2.1346-1354.2006.

Palojärvi, A. (2006). Phospholipid Fatty Acid (PLFA) analyses. In J. Bloem, D.W. Hopkins \& A. Benedetti (Eds.), Microbiological methods for assessing soil quality (pp. 204-211). Wallingford: CABI Publishing.

Pinkart, H.C., Ringelberg, D.B., Piceno, Y.M. Macnaughton, S.J. \& White D.C. (2002). Biochemical approaches to biomass measurements and community structure analysis. In C.J. Hurst (Ed.), Manual of environmental microbiology (pp. 101-113). Washington: ASM Press.

Ringelberg, D.B., Stair, J.O., Almeida, J., Norby, R.J., O’Neill, E.G. \& White D.C. (1997). Consequences of rising atmospheric carbon dioxide levels for the belowground microbiota associated with white oak. J. Environ. Qual., 26, 495-503. DOI: 10.2134/jeq1997.0047242500. 2600020022x.

Rousk, J., Brookes, P.C. \& Bååth E. (2010). The microbial PLFA composition as affected by pH in an arable soil. Soil Biol. Biochem., 42, 516-520. DOI: 10.1016/j.soilbio.2009.11.026.

Ryan, M.G., Melillo, J.M. \& Ricca A. (1990). A comparison of methods for determining proximate carbon fractions of forest litter. Can. J. For. Res., 20, 166-171. DOI: 10.1139/x90-023.

Sakamoto, K., Iijima, R. \& Higuchi R. (2004). Use of specific phospholipid fatty acids for identifying and quantifying the external hyphae of the arbusbular mycorrhizal fungus Gigaspora rosea. Soil Biol. Biochem., 36, 1827-1834. DOI: 10.1016/j.soilbio.2004.04.037.

Shotyk, W., Goodsite, M.E., Roos-Barraclough, F., Frei, R., Heinemeier, J., Asmund, G., Lohse, C. \& Hansen T.S. (2003). Anthropogenic contributions to atmospheric $\mathrm{Hg}, \mathrm{Pb}$, and As accumulation recorded by peat cores from southern Greenland and Denmark dated using the 14C "bomb pulse curve". Geoch. Cosm. Acta, 67, 3991-4011. DOI: 10.1016/S0016-7037(03)00409-5.

Stanová, V. (2000). Current distribution and threats to peatlands in Slovakia (in Slovak). In V. Stanová (Ed.), Rašeliniská Slovenska (pp. 3-9). Bratislava: DAPHNE - Inštitút aplikovanej ekológie.

Tatzber, M., Stemmer, M., Spiegel, H., Katzlberger, C., Haberhauer, G. \& Gerzabek M.H. (2007). An alternative method to measure carbonate in soils by FT-IR spectroscopy. Environ. Chem. Lett., 5, 9-12. DOI: 10.1007/ 
s10311-006-0079-5.

ter Braak, C.J.F. (1994). Basic theory and linear methods. Canonical community ordination. Part I. Ecoscience, 1, 127-140.

ter Braak, C.J.F. \& Smilauer P. (2002). CANOCO reference manual and CanoDraw for Windows user's guide: software for canonical community ordination (version 4.5). Itaca: Microcomputer power. www.canoco.com.

Trofymow, J.A., Moore, T.R., Titus, B., Prescott, C., Morrison, I., Siltanen, M., Smith, S., Fyles, J., Wein, R., Camire, C., Duschene, L., Kozak, L., Kranabetter, M. \& Visser S. (2002). Rates of litter decomposition over 6 years in Canadian forests: influence of litter quality and climate. Can. J. For. Res., 32, 789-804. DOI: 10.1139/x01-117.

Vallejo, V.E., Arbeli, Z., Terán, W., Lorenz, N., Dick, R.P. \& Roldan F. (2012). Effect of land management and Prosopis juliflora (Sw.) DC trees on soil microbial community and enzymatic activities in intensive silvopastoral systems of Colombia. Agric. Ecosyst. Environ., 150, 139-148. DOI: 10.1016/j.agee.2012. 01.022.

Van Roon, M.R. (2012). Wetlands in the Netherlands and New Zealand: Optimising biodiversity and carbon sequestration during urbanisation. J. Environ. Manag., 101, 143-150. DOI: 10.1016/j.envman.2011.08.026.

Vávřová, P., Penttilä, T. \& Laiho R. (2009). Decomposition of Scots pine fine woody debris in boreal conditions: Implications for estimating carbon pools and fluxes. For. Ecol. Manag., 257, 401-412. DOI: 10.1016/j. foreco.2008.09.017.

Weiss, R., Shurpali, N.J., Sallantaus, T., Laiho, R., Laine, J. \& Alm J. (2006). Simulation of water table level and peat temperature in boreal peatlands. Ecol. Model., 192, 441-456. DOI: 10.1016/j.ecolmodel.2005.07.016.

Welc, M., Frossard, E., Egli, S., Bünemann, E.K. \& Jansa J. (2014). Rhizosphere fungal assemblages and soil enzymatic activities in a 110-years alpine chronosequence. Soil Biol. Biochem., 74, 21-30. DOI: 10.1016/j.soilbio.2014.02.014.

White, D.C., Davis, W.M., Nickels, J.S., King, J.D. \& Bobbie R.J. (1979). Determination of the sedimentary microbial biomass by extractible lipid phosphate. Oecologia, 40, 51-62. DOI: 10.1007/BF00388810.

White, D.C., Pinkart, H.C. \& Ringelberg D.B. (1997). Biomass measurements: biochemical approaches. In C.H. Hurst, G. Knudsen, M. McInerney, L.D. Stetzenbach \& M. Walter (Eds.), Manual of environment microbiology (pp. 91-101). Washington: American Society for Microbiology Press.

Wieder, R.K. \& Starr S.T. (1998). Quantitative determination of organic fractions in highly organic, Sphagnum peat soils. Commun. Soil Sci. Plant Anal., 29, 847-857. DOI: 10.1080/ 00103629809369990.

Wilson, L., Wilson, J., Holden, J., Johnstone, I., Armstrong, A. \& Morris M. (2011). Ditch blocking, water chemistry and organic carbon flux: Evidence that blanket bog restoration reduces erosion and fluvial carbon loss. Sci. Total Environ., 409, 2010-2018. DOI: 10.1016/j.scitotenv.2011.02.036.

Zak, D.R., Ringelberg, D.B., Pregitzer, K.S., Randlett, D.L., White, D.C. \& Curtis P.S. (1996). Soil microbial communities beneath Populus grandidentata grown under elevated atmospheric CO2. Ecol. Appl., 6, 257-262. DOI: $10.2307 / 2269568$.

Zelles, L. (1997). Phospholipid fatty acid profiles in selected members of soil microbial communities. Chemosphere, 35, 275-294. DOI: 10.1016/S0045-6535(97)00155-0.

Zelles, L. (1999). Fatty acid patterns of phospholipids and lipopolysaccharides in the characterisation of microbial communities in soil: a review. Biol. Fertil. Soils, 29, 111-129. DOI: 10.1007/s003740050533.

Zogg, G.P., Zak, D.R., Ringelberg, D.B., MacDonald, N.W., Pregitzer, K.S. \& White D.C. (1997). Compositional and functional shifts in microbial communities due to soil warming. Soil Sci. Soc. Am. J., 61, 475-481. DOI: 10.2136/ sssaj1997.03615995006100020015x. 